\title{
The responsibility of futurists in strategic foresight - Hungarian examples
}

\author{
Erzsébet Nováky ${ }^{*}$, Gergely Tyukodi ${ }^{1}$ \\ Corvinus University of Budapest, Futures Studies Department, Fővám tér 8., Budapest, H-1093, Hungary
}

\section{A R T I C L E I N F O}

\section{Article history:}

Received 31 March 2010

Received in revised form 19 June 2010

Accepted 21 June 2010

Available online xxxx

Keywords:

Strategic foresight

Regional competitiveness

Socialism

Social trends

Hungary

\section{Introduction}

The Futures Studies Department at the Corvinus University of Budapest conducted a few $\$ 3$ strategic foresight projects at the beginning of the twenty-first century. The goals of two 94 projects were to increase the regional competitiveness of two towns in Hungary; whereas, two 19 other projects dealt with the long-term, 15- to 20- year-long, macro-development opportunities of Hungary. They focused on defining social trends that influence the long- 17 term decision-making environment of the regions and the country. The two types of experience 18 made it possible to enhance strategic foresight by defining the role and responsibility of 23 professional futurists and average, everyday people.

(c) 2010 Published by Elsevier Inc.

26
28
28

Hungary experienced a radical change in the 1990s: a mix of political transition from socialism to democracy, an economic 32 change and, as a result, a social transformation. The change shocked the country in many ways. First, the adaptation of the national 33 economy resulted in a sudden decrease of economic production while the social transformation included the quick 34 impoverishment of the elder and undereducated. After the transition, Hungary was quickly introduced to the world of 35 uncertainties, thus this young democratic society had to learn how to navigate and make decisions.

The new game required new rules. The long-term mechanical planning used during the socialist period proved to be a useless 37 tool for making decisions in such a turbulent world, but still, the need for looking ahead persisted. Scenario-making and strategic 38 foresight became popular decision-making tools in business and regional development related to the future. As the Hungarian 39 economy opened up to international business, multinational companies from more developed Western societies quickly 40 introduced foresight tools to the Hungarian international business sphere. Hungarian-owned businesses, mainly small- and 41 middle-size enterprises, were not likely to apply those methods, since they had a more simple strategy at that point: their main 42 goal was to survive, to make some profit, and become suppliers for bigger international retailers in order to have possibly long- 43 term contracts. At the same time, the academic field started to pay more attention to foresight and futures studies as it came to 44 realize the need to think about the future in the more complex and uncertain environment. Interestingly, the public sector was 45 more open to these new tools, especially with the promise of joining the EU in the mid-1990s. Regional planning thus started to 46 gain momentum in public affairs while academic knowledge met public demand.

\section{From local to national foresight}

One of the main driving ideas that supported the application of foresight came from the European Union guidelines [1] to 49 enhance regional competitiveness. In the field of futures studies, the Futures Studies Department (FSD) at the Corvinus University 50

\footnotetext{
* Corresponding author. Tel.: + 3614825319.

E-mail addresses: erzsebet.novaky@uni-corvinus.hu (E. Nováky),gergely.tyukodi@uni-corvinus.hu (G. Tyukodi).

1 Tel.: + 3614825319 .
}

0040-1625/\$ - see front matter (C) 2010 Published by Elsevier Inc.

doi:10.1016/j.techfore.2010.06.013 
of Budapest focused on innovative futures methods, on the renewal of futures studies methodology including foresight. The FSD $5 \mathbf{3}$ applied the new methodology and new tools to research projects in the field of foresight. Four examples will be introduced here. 56

\subsection{Local foresight projects}

As the new millennium began, the FSD conducted two projects that sought to increase regional competitiveness in two 58 Hungarian towns. One was a small village, Tuzsér, close to the Ukrainian border with Hungary, in one of the most underdeveloped 59 parts of the country [2]. The other project was carried out for a regional center, Kiskunfélegyháza, a medium-size town in south- 60 eastern Hungary, an area characterized by intensive agricultural activities [3]. The aim of these strategic foresight projects was to 61 create a long-term sustainable strategy for the regions. In order to ensure success, a complex approach involving local stakeholders 62 in a participatory collective decision-making process was applied in the projects.

In the case of Tuzsér, the Delphi method was chosen in order to collect the ideas and opinions of participants. More specifically, 64 it was a Policy Delphi [4] that aimed at structuring and discussing diverse views of the preferred future that was applied. Three 65 public Delphi rounds formed the basis of the process that gave the opportunity to participants, stakeholders (community leaders, 66 members of municipalities, company representatives and ordinary citizens) to come up with a joint vision where they imagined 67 the community would be in different time frames (from 5 up to 20 years). The goal of the first round was to address the key areas 68 that the community should have focused on, the second round concentrated on the possible developments of the region and on 69 identifying key actions of implementation. An important part of the process was to define the required time frame of the 70 alternatives. The research targeted at making the vision more robust and ready to handle uncertainties, thus in the third round of 71 the survey, scenarios were created as participants grouped the possible actions according to their priorities and time frame. The 72 explanation of the alternative scenarios added a strong narrative element which helped participants to visualize and internalize 73 the stories and discuss the advantages, disadvantages, plus the opportunities and threats of the scenarios (to read more about the 74 narrative aspect of scenario-building see [5]). After the participants discussed the importance of the alternative scenarios, the first 75 draft of the vision was adjusted with the new comments, and participants came up with major milestones and strategic actions 76 required to implement the vision.

The second local foresight project in Kiskunfélegyháza was very similar; however, the different situation of the two towns 78 required reorganizing the flow of the research. Similar to the previous case, the Kiskunfélegyháza project consisted of a three- 79 round public Delphi process, but this time it focused on three critical areas in all three rounds, specifically to find:

o the external forces that influence the societal-economic areas of the town;

o the forces inherent in the local management; and

o the civil communities' and citizens expectations for the future.

Based on the outcomes of the survey, alternative scenarios were created for the possible development of the community. Key 84 areas were defined to which the stakeholders had to pay in order to implement the preferred scenario.

A new element in the projects was the participatory dimension as not only experts, but also stakeholders were involved in this 86 process which offered interesting results. One of them was the realization of how the combination of different methods (in our 87 cases public Delphi with a participatory approach and scenario building) can lead to a significantly better decision-making process 88 and to a more complex foresight activity. The Delphi survey was suitable to collect all stakeholders' opinions and contrast the 89 different views, while the scenario-building phase then offered a deeper insight into the Delphi results by "making the alternatives 90 come alive".

Another important experience was finding out how to make people cope and work together in order to make common 92 decisions. This was something they had not known in the earlier 40 years of the socialist era. People were not at all used to 93 anything like interest articulation and representation. Some of them (especially ordinary citizens) had problems even identifying 94 their very own interest. In Hungary, non-governmental organizations (NGOs) are still weak. There are simply not many interest 95 groups and only a few grass-roots movements that could help and make people practice both finding and articulating their 96 interests. The main challenge of the projects was to apply these futures studies methods in these circumstances; in other words, to 97 motivate people to participate then support them in identifying their individual interests, to accept the community's values and 98 objectives and to come up with new ideas. Socialism established a special social defence system whereby people were not allowed 99 to express their views and interests. As a result, it became the norm to undermine top-down decisions, not to follow the official 100 expectations, thus to find one's own (secret) way of success. The system and the people in it were very individualistic. The 101 challenge in the foresight project was to come up with not only the sum of the individualistic decisions, but rather to harmonize 102 them, and to help the community to find its goals. The members of the community needed a path that they could walk together 103 since in the long run it is certainly more effective for all participants to cooperate.

\subsection{National foresight projects}

The other two strategic foresight projects dealt with the long-term, 15 to 20-year-long, macro- development opportunities of 106 Hungary. These projects focused on defining social trends that influence the long-term decision-making environment of the 107 country in order to identify the key areas that could strengthen the role of the country within Central Eastern Europe. Various 108 futures studies tools were applied to find the relevant forces and, based on the issues addressed, possible scenarios were built for 109 2025. 
In the first project, between 1997 and 2000, the goal was to identify possible alternative futures for Hungary [6]. This was one of 111 the first foresight projects in Hungary with a goal of finding nationwide alternative futures instead of predicting the probable one. 112 Since the project was conducted just after a transition period, a lot of uncertainty remained in the air. The focus was placed on the 113 expectations of individuals, institutions and enterprises, and the project tried to address the areas on which the country should 114 have concentrated in order to arrive at a sustainable growing path. Participants completed surveys that offered the opportunity to 115 have bottom-up ideas and top-down observations. Based on the output of the surveys, eight different possible scenarios were 116 drawn up. These were analyzed according to the extent to which they were acceptable to the society in order to see how well 117 supported the different scenarios could have been. The scenario analysis clustered around the following special aspects: 118 1) expectations of the accession of Hungary to the European Union (EU);2) expected new and emerging main values and expected 119 aspirations of individuals. Since it was difficult to differentiate between the eight scenarios generated, these were grouped from 120 two additional points of view: 1) whether the process of the scenario development was stable or unstable and 2) whether 121 inhabitants preferred changes or not. With this analysis, by the end of the project, it was possible to describe the opportunities for 122 Hungary and to identify the most important points of the four different possible developments. No complete strategies were 123 created within this project, but the complex alternative scenarios that were developed did provide good starting points for the 124 decision-makers to see where the country was heading and what they need to do in order to change that baseline future. The most 125 important opportunity in this case was to change the environment to make it more unstable so as to open the space to new ideas 126 and influence the behavior of people so they might be ready for change as well as accept and support it.

In 2007, the Hungarian Academy of Sciences commissioned the other national foresight project in which the FSD actively 128 participated and sought to describe possible developments of Hungary in the following 18 years. This project also sought to 129 identify key areas in which individuals within society can be influenced to act towards putting the country on a more desired 130 developmental path [7]. The project scope was to focus on social, technological and ecological issues at an individual and a social 131 level, as these fields are less emphasized for the broader public, but contain significant opportunities for the future.

The first step of the national foresight project consisted of two different parts. In the first part, experts were asked to describe 133 what the expected and possible futures were in their fields of expertise in order to see what the likely developments, expectations, 134 hopes and fears for the long-term future were. Given the long-term time frame, most expert analysis focused on developments 135 that evolve over a long period, sometimes these had not existed at the time of the research. Based on the results of the research, the 136 expected future generation was surveyed. Naturally they are likely to be the most important decision-makers in the time frame of 137 the project. As a result, the current young generation (between the ages of 17 and 23) was asked about their ideas and 138 expectations regarding the previously identified forces of change. In the second step of the research, future alternatives were 139 created from the confrontation of the experts' forecasts and the next generation's expectations. The key driving forces found made 140 it possible to identify the most important bifurcation points that could take the country to the different scenarios. The basis of 141 decision-making was, therefore, a set of complex future alternatives with defined driving forces.

The two national projects had some interesting peculiarities. First, the contractor was an academic institution, but the target group, 143 the group to whom the results were addressed, was supposed to be the whole society. The framework of the project was not supposed 144 to create a long-term strategy for Hungary or to create proposals for important actions or even to offer some decisions. Instead, the 145 ideas of the projects were to address the critical turning points that could lead to significantly different futures for the country, and 146 possibly describe what the motivation of people could be in the different alternatives. Overall, the objective of the project was also very 147 special: not just to describe possible changes that can happen to the society, but also to motivate change on the level of the individual 148 by describing the different outcomes. The third interesting characteristic of the projects was the focus on social trends and on social 149 creativity. The biggest challenge with social trends and social creativity are that they remain difficult to measure. Similarly, the 150 questions that they raise are difficult to communicate to the broader public; in other words, to the target group of the research. The 151 goal of the project became quite special from this point of view: the research focus was on individual levels in motivation and action, 152 while the key points of the analyses were about possible and expected developments in the different fields of life.

\section{Lessons from these experiences}

The common element and common findings of the research projects were the following:

o Education is a critical element since it is still not a common task to teach people how to look into the future. By taking part in the 156 projects, participants already gained some insight into the importance of foresight; however, much more training is still 157 needed to develop foresight into a skill. It is also an important educational task in Hungary to teach people to think about 158 changes, to make them to think about the possible consequences of their decisions, and even to identify their own interests. 159 Due to the heritage of the previous era, most people still do not believe they have any influence on the future that could also be 160 changed with education;

o The outputs of the projects were three-sided. One output was created for the client who ordered the project. It described the 162 possible future alternatives in order to support their decisions. Another type of output was made for the academic sector in 163 order to renew the methodology, foresight, and futures studies as well as to support the application of the methods in the 164 Hungarian context, while the third output was for the public in order to strengthen dissemination;

o The overall goals of the projects were to raise awareness of the future in the community.

By discovering different future alternatives and presenting them to the broader public sphere, futurists inevitably engage in 167 normative activities. The idea of this initiative is to present possible threats and hopes thus motivating people to take steps 168 
towards a potentially better future. However, a major question arises: What is the responsibility of futurists, foresight experts, 169 researchers when dealing with topics like the above-mentioned ones? In addition, it is also important to know what the 170 responsibility of the average person is.

\section{Responsibility of futurists and ordinary people}

Since futurists are experts who always think and act towards recognizing and influencing the future, especially the long-term 173 future, their responsibility for the future is more complex than the responsibility of other experts and other people. This complex 174 responsibility is based on the following four dimensions:

o future alternatives need to be well-prepared and complex: experts' opinions are valuable as they can give insight into 176 important trends and developments influencing the future of society, economy, technology and the environment. However, the 177 opinion of the average person should also be included since it reflects values and attitudes that can reinforce or weaken those 178 trends and developments;

o future alternatives need to be communicated and future knowledge needs to be disseminated to the greater public;

o responsibility also applies to the implementation of the future alternative that is chosen and accepted by the community; and 181

o responsibility needs to be dynamic: a futurist's task is also to monitor changes in order to ensure early adaptation and proactive 182 strategy.

Futurists are responsible for strengthening future sensitivity and the openness of society and its members, too. On the other hand, 184 futurists alone cannot be responsible for the creation and the implementation of desired/accepted future alternatives. In today's 185 society, social actors have a new, more direct, connection to the future. They enjoy greater freedom in decision-making and can 186 strengthen different directions of changes. In this sense, they can promote the creation of significantly different future alternatives. 187

Yet, everyday folk can take up this responsibility only if their thinking is future-oriented, if they are participative, which means 188 they can be involved in building a joint future, and if they are able to act on constructive aggression, a form of aggression [8] that 189 enforces positive action in circumstances where the need of positive action is not obvious to everybody. Openness; willingness to 190 try something new; togetherness; the forward-thinking and acting of the society overall appear in these three phenomena. Future 191 orientation is the ability people use to make decisions and actions inspired more by their future intention, expectations, goals and 192 desires than by their past experiences. In this sense, the main driving force of their action is the expected future, [9] which remains 193 the most important factor that influences the responsibility of ordinary people for the future.

Individual future-orientation is not enough, though, because the future can only be created with a basis of cooperation. 195 Participation is thus essential and needed in order to create a joint responsible and harmonious future since cooperation with 196 others ensures that selfish individual interests are not the only thing at the core of forming the future, but also that others' interests 197 and characteristics are taken into account. Feeling the importance of participation and actually taking part supports the fact that 198 we pay attention to the community and to our environment. In order to be able to make change, it is important to realize and apply 199 constructive aggression. Formal and informal education through schools, experts and social networks provide an important tool to 200 help people develop these new skills and attitudes.

The responsibility of futurists and everyday people are connected; indeed, they support each other. Futurists not only assist 202 non-professionals in practicing their responsibility, but they also may offer a kind of positive example about what responsible 203 thinking and acting could mean in terms of the future. In favorable cases, the whole society creates a positive, responsible future- 204 influencing force, however in many cases, this is not happening. Many just live their lives without realizing that they build the 205 future, and many do not try to make a positive difference as they think they are not strong enough to do so. Driving forces are only 206 responsible for the future if the future-influencing forces, responsibility, participation, action and creativity are in harmony.

\section{References}

[1] The Treaty of Lisbondownloaded from, http://eur-lex.europa.eu/JOHtml.do?uri=OJ:C:2007:306:SOM:EN:HTML 2007(16 May, 2010).

[2] E. Nováky, Tuzsér település és a Felső-Szabolcsi Kistérség jövője, Future of the settlement Tuzsér and the small region Felső-Szabolcs, Budapesti 210 Közgazdaságtudományi Egyetem, Budapest, 2000.

[3] E. Nováky, Kiskunfélegyháza jövője a participatív jövőkutatás szemléletében, Future of the town Kiskunfélegyháza in the participatory futures studies point of 212 view, Budapesti Közgazdaságtudományi és Államigazgatási Egyetem, Budapest, 2003.

[4] The Delphi Method, in: H.A. Linstone, T. Murray (Eds.), Techniques and Applications, 1 . http://www.is.njit.edu/pubs/delphibook/.

[5] B. Rasmussen, The narrative aspect of scenario-building - how story telling may give people a memory of the future, AI\&Society 19 (3) (2005) 229-249.

[6] Magyarország holnap után, in: E. Nováky (Ed.), Hungary’beyond tomorrow, Budapesti Közgazdaságtudományi és Államigazgatási Egyetem, Budapest, 2001.

[7] Magyarország 2025, in: E. Nováky (Ed.), Hungary in the Year 2025, Gazdasági és Szociális Tanács, Budapest, 2010.

[8] I. Kappéter, A konstruktív agresszió és a jövő formálása, Constructive aggression and forming the future, Püski Kiadó, Budapest, 2007.

[9] E. Nováky, E. Hideg, I. Kappéter, Future orientation in Hungarian society, Futures 26 (7) (1994) 759-770.

Erzsébet Nováky, PhD, DSc, is Head of Futures Studies Department, Corvinus University of Budapest, and president of the Committee on Futures Research, 222 Hungarian Academy of Sciences. Her main interests are the methodology of futures studies and the socio-economic futures of Hungary.

Gergely Tyukodi is a doctoral student, Futures Studies Department, Corvinus University of Budapest, and a financial expert. His main research interests are future 225 management and futures studies methodology. 